\title{
Effect of Kaolin and Fulvic Acid Antitranspirants on Tomato Plants Grown under Different Water Regimes
}

\author{
Aggag, A.M.; Alzoheiry, A.M. and Abdallah, A.E. ${ }^{1}$
}

\begin{abstract}
This study was carried out to evaluate effects of kaolin (KA) and fulvic acid (FA) as antitranspirants (ATs) on relative water content (RWC) of leaves, net $\mathrm{CO}_{2}$ assimilation rate $\left(\mathrm{CO}_{2} \mathrm{AR}\right)$, yield, fruit quality and irrigation water use efficiency (IWUE) of tomato plants (Solanum lycopersicum L.). The plants were grown under three water regimes based upon crop daily water consumptive use (ETc). These regimes included $100 \%$ ETc, $75 \%$ ETc and $50 \%$ ETc. Field experiments were achieved for two successive seasons 2012 and 2013 under drip irrigation system in sandy soil at El-Bostan, El-Beheira Province, Egypt. The results revealed that both ATs enhanced effectively the physiological activities and yield production of tomato plants, particularly at water regime of $75 \%$ ETc, but they did not compensate the negative effects caused by sever water regime of $50 \%$ ETc. FA antitranspirant was more effective than KA. Under water regime of $75 \% \mathrm{ETc}$, application of $1.5 \mathrm{FA} \mathrm{ml} \mathrm{L}^{-1}$ at 21-day intervals increased IWUE by $34.82 \%$ compared to untreated plants. Foliar spray by FA reduces the values of crop response factor than KA in the two seasons. These led to conserving soil water and thereby reduce the applied water by $25 \%$ of irrigation water. In comparison to untreated FA plants, the FA $(\mathbf{7 5 \%}$ ETc) led to decreases in the yield to $93.4 \%$ of that irrigated at $100 \%$ ETc. There were no significant differences in the fruit quality (titratable acidity and vitamin $C$ ) between both ATs treatments.
\end{abstract}

Key Words: Water use efficiency, Kaolin, Fulvic acid, irrigation regimes, fruit quality

\section{INTRODUCTION}

Because of the lack of water in arid regions, there is a great need to optimize agricultural water consumption. Thus, water conserving is becoming a decisive consideration for agriculture, particularly in arid and semi-arid regions (i.e. Egypt) where water is the main limiting factor for plant growth (Moftah and ALHumaid 2005). Indeed, plants are prodigal in the water use because approximately $5 \%$ of water uptake is used for its growth and development while the remaining $95 \%$ is lost for transpiration (Prakash and Ramachandran 2000b). One way to achieve water conservation in the agricultural sector is to reduce the transpiration rate (TR) of a plant. Studying the effects and potential uses of antitranspirants (ATs) on plant growth showed particular possibilities for conserving irrigation water, increasing water use efficiency. However, ATs applications for this purpose would be justified only if water costs are sufficiently high (Glenn et al., 2005).

ATs are classified into three types based on their action role: (1) reflecting materials: they reduce the absorption of radiant energy and thereby reduce leaf temperatures and TR, (2) film forming materials: they are certain emulsions of wax, latex or plastics dries on the foliage to form thin transparent films which hinder the escape of water vapor from the leaves, and (3) metabolic materials: chemical compounds can prevent stomata from opening fully (by affecting the guard cells around the stomata pore), thus decreasing the loss of water vapor from the leaf (Glenn et al., 2005).

Early studies demonstrated that the foliar spray by reflective Kaolin had improved both plant water status and yield of water-stressed tomato plants, while it did not reduce carbon assimilation (Glenn et al., 2003). Many studies have focused on comparing the effects of reflective ATs on vegetables (Prakash and Ramachandran 2000a), fruits (Glenn et al., 2003) and field crops (Gupta et al., 2001). Kaolin application on trees was found to (i) reduce plant TR (Cantore et al., 2009; and Rosati et al., 2006) and to improve whole canopy assimilation rate under high leaf-to-air vapor pressure deficit and temperature (Rosati et al., 2006), or to have no effect (Wünsche et al., 2004) in apple; (ii) reduce the outer canopy assimilation rate and maximum leaf assimilation rate at saturating light in apple (Grange et al., 2004); (iii) increase $\mathrm{CO}_{2} \mathrm{AR}$ rate, stomatal conductance and water use efficiency at mid-day in citrus (Jifon and yvertsen, 2003); and (iv) reduce leaf temperature, without affecting TR, stomatal conductance, net $\mathrm{CO}_{2}$ assimilation and yield in pecan tress (Lombardini and Glenn, 2005). Kaolin caused a reduction in temperature of vegetation and TR in tea (Anandacoomaraswamy et al., 2000), a decrease in leaf temperature in tomato (Saavedra et al., 2006), and no effect on yield, leaf temperature, TR, net $\mathrm{CO}_{2}$ assimilation or stomatal conductance in pepper (Russo and Díaz-Pérez, 2005).

\footnotetext{
${ }^{1}$ Dept. Natu. Res. \& Agric. Eng., Fac. Agric., Damanhour Univ. (www.damanhour.edu.eg)

Corresponding author: A.M. Aggag, aaggag5@dmu.edu.eg

Received May 6, 2015, Accepted June 15, 2015
} 
Humic substances (Fulvic acid and Humic acid) have been used to regulate the plant growth under well watered and drought conditions (Li et al., 2005). Furthermore, fulvic acid as metabolic ATs is an organic acid and nontoxic and available compared with the other chemicals used. It is also not expensive and did not cause pollution problems as a result of extensive use (Nardi et al., 2002). Anjume et al., (2011) reported that Fulvic acid increased chlorophyll and water content of leaves, thus drought stress can be mitigated. Fulvic acid also increased photosynthesis, reduced stomatal opening status and TR, thus led to growth stimulation and water loss reduction. Falvic acid foliar spray resulted in an increase of grain yield by $7.2 \%$ at the optimal concentration of $1.5 \mathrm{ml} \mathrm{L}^{-1}$ (Li et al., 2005).

The objective of the present study was to evaluate the effects of Fulvic acid (metabolic AT type) and Kaolin particle film (reflecting AT type) on irrigation water use efficiency (IWUE), physiological performance, tomato plant response to water stress, plant water status, photosynthesis rate, yield and fruit quality of tomato plants grown in sandy soil under different water regimes.

\section{MATERIALS AND METHODS}

The experimental work, crop evapotranspiration, measurements, and fruit quality and statistical analysis are presented.

\section{A: Experimental work}

A field experiment was conducted in 2012 and 2013 growing seasons at El-Bostan Farm Experiment Station, Faculty of Agriculture, Damanhour University, El-Behera province, Egypt. El-Bostan region is located between $30.20 \mathrm{~N} \& 30.50 \mathrm{E}$ and altitude $7.4 \mathrm{~m}$ above sea level. The climate is typically arid, characterized by average annual rainfall of $20-50 \mathrm{~mm}$ distributed mainly during winter, with air temperature ranges between 30 $38{ }^{\circ} \mathrm{C}$ in summer. The soil of the experimental field represents the newly reclaimed lands at the western area of Nile Delta. The main chemical and physical properties of the soil are: $\mathrm{pH}$ of 8.2 ; organic matter content of $0.2 \%$; total carbonate of $3.3 \%$; electrical conductivity $\left(\mathrm{EC}_{\mathrm{e}}\right)$ of $0.75 \mathrm{dSm}^{-1}$, SAR of 0.35 , bulk density of $1.7 \mathrm{Mg} . \mathrm{m}^{-3}$; wilting point of $0.09 \mathrm{~m}^{3} . \mathrm{m}^{-3}$, field capacity of $0.14 \mathrm{~m}^{3} \cdot \mathrm{m}^{-3}$ and saturation water content of $0.33 \mathrm{~m}^{3} \cdot \mathrm{m}^{-3}$. The soil texture is sandy (96.1, 2.2 , and $1.7 \%$ for sand, silt and clay, respectively).

The field studied area was divided into 27 plots (experimental unit). Each unit consists of two rows with 7-m length and 2.6-m apart $\left(18.2 \mathrm{~m}^{2}\right)$. Prior to tomato cultivation, tomato (Solanum lycopersicum L. super hybrid cultivar) seeds were sown in polystyrene trays on $10^{\text {th }}$ and $5^{\text {th }}$ of February, 2012 and 2013, respectively. Seedlings and germination stages were conducted in a greenhouse. Seedlings were transplanted at the third true leaf stage on $10^{\text {th }}$ and $8^{\text {th }}$ of March 2012 and 2013, respectively in rows at apace of 0.4-m between plants, giving a plant density of 2 plants $\mathrm{m}^{-2}$. A drip irrigation system was used for tomato irrigation. The system includes lateral sets along the plant rows with in-line emitters' spaced $0.40-\mathrm{m}$ apart and they possess a flow rate of $4.2 \mathrm{~L} \mathrm{~h}^{-1}$. The laterals were placed $0.10 \mathrm{~m}$ away from the plant rows. The irrigation water discharge was measured using a flow meter installed in the water delivery unit, which was designed for independent control of water delivery to each desired evapotranspiration rate. Three water regimes combined with two foliar applications of ATs materials were achieved. A control treatment (untreated ATs) was conducted for each irrigation regime as well. The first foliar spray was applied on $25^{\text {th }}$ of April at the start of fruit set and repeated every 21-day intervals for three applications. The ATs were applied to plants using a backpack power sprayer. Irrigation regimes (main plot) were selected as a percentage of crop daily water consumptive use (ETc). These regimes were $100 \%$ ETc, $75 \% \mathrm{ET}_{\mathrm{c}}$ and $50 \% \mathrm{ET}_{\mathrm{c}}$. Under each level of irrigation, two types of ATs materials were applied (sub plot). Antitranspirants treatments were (1) spraying kaolin with concentration of $4 \%(\mathrm{w} / \mathrm{v})$ as reflective ATs, (2) spraying fulvic acid with concentration of $1.5 \mathrm{ml} \mathrm{L}^{-1}$ as metabolic ATs and (3) control (untreated ATs). All treatments were achieved using three replicates.

\section{B: Crop Evapotranspiration (ETc)}

The reference evapotranspiration $\left(\mathrm{ET}_{0}\right)$ was calculated by FAO Penman-Monteith equation using FAO-CROPWAT (software version 8) (Allen et al., 1998). Crop daily water consumptive use (ETc) was obtained by multiplying $\mathrm{ET}_{0}$ by Kc. The same software was used to calculate both the net irrigation requirements (NIR) and gross irrigation requirements (GIR) and irrigation intervals. FAO-CROPWAT was used to calculate ETm (a maximum evapotranspiration at $100 \%$ ETc) and ETa (an actual evapotranspiration at $75 \%$ ETc and $50 \%$ ETc) in $\mathrm{m}^{3} \mathrm{ha}^{-1}$.

\section{C: Measurements}

Relative water content (RWC) was calculated according to (De Pascale et al., 2003) using:

$$
R W C=\frac{(F W-D W)}{(T W-D W)} \times 100
$$

Where: TW is leaf turgid weight, FW is leaf fresh weight and DW is leaf dry weight in $\left(\mathrm{Kg} \mathrm{ha}^{-1}\right)$

Canopy Temperature $(\mathrm{Ct})$ Was measured between 12:00 and 14:00 $\mathrm{h}$, on top of plants using an IR thermometer (model 112C; Ev 
erest Interscience, Tustin, CA) , Net $\mathrm{CO}_{2}$ Assimilation Rate was measured with a portable photosynthetic open-system (Li-6400 USA). Yield Components, marketable and unmarketable yields were measured, where fruit that were green, cracked, with symptoms of blossom-end rot, sunscald, or damaged by tomato fruit worm were considered unmarketable.

Irrigation Water Use Efficiency (IWUE) was calculated using the following equation:

$$
I W U E=\frac{\text { Marketable Yield }\left(\mathrm{kg} \mathrm{ha}^{-1}\right)}{\text { Consumptive Use }\left(\mathrm{m}^{3} \mathrm{ha} \mathrm{a}^{-1}\right)}
$$

Tomato Water Response Factor (Ky) is a factor that is defined as the decrease in yield per unit decrease in ETc (Singh et al., 2010). Seasonal values of Ky was calculated for each experimental year as:

$$
1-\frac{Y_{a}}{Y_{m}}=K y\left(1-\frac{E T_{a}}{E T_{m}}\right)
$$

Where: $\mathrm{Y}_{\mathrm{m}}$ and $\mathrm{Y}_{\mathrm{a}}\left(\mathrm{kg} \mathrm{ha}^{-1}\right)$ are maximum and actual yield, respectively. $\mathrm{ET}_{\mathrm{m}}$ and $\mathrm{ET}_{\mathrm{a}}\left(\mathrm{m}^{3} \mathrm{ha}^{-1}\right)$ are maximum and actual evapotranspiration, respectively. Ky was calculated for marketable yield produced by the crop.

\section{D: Fruit quality analysis}

Titratable acidity ( $\mathrm{mg} / 100 \mathrm{ml}$ juice) determined by titrating five $\mathrm{ml}$ of tomato juice with $0.1 \mathrm{M}$ of $\mathrm{NaOH}$ in the presence of phenolphthalein, Total Soluble Salts (TSS) in tomato juice was determined using a refractometer and expressed as Brix at $20^{\circ} \mathrm{C}$. Vitamin $\mathrm{C}$ (mg Ascorbic acid $/ 100 \mathrm{ml}$ of tomato juice) was measured by titrating the pigment solution with $\mathrm{NaOH}$ in the presence of the acid indicator.

\section{E: Statistical Analysis}

Table 1. Amounts of applied irrigation water $\left(\mathrm{m}^{3} / \mathrm{ha} / \mathrm{stage}\right)$, number of irrigations and number of days for each growth stage for the two growing seasons

\begin{tabular}{lcccccc}
\hline \multirow{2}{*}{ Growth Stage } & \multicolumn{2}{c}{$\begin{array}{c}\text { Gross irrigation } \\
\text { requirements } \\
\text { ( } \mathbf{m}^{\mathbf{3} / \text { period) }}\end{array}$} & $\begin{array}{c}\text { Growth stage } \\
\text { length (days) }\end{array}$ & \multicolumn{2}{c}{$\begin{array}{c}\text { Number of } \\
\text { irrigations/ stage } \\
\text { length }\end{array}$} \\
\cline { 2 - 7 } & $\begin{array}{c}\text { First } \\
\text { season }\end{array}$ & $\begin{array}{c}\text { Second } \\
\text { season }\end{array}$ & $\begin{array}{c}\text { First } \\
\text { season }\end{array}$ & $\begin{array}{c}\text { Second } \\
\text { season }\end{array}$ & $\begin{array}{c}\text { First } \\
\text { season }\end{array}$ & $\begin{array}{c}\text { Second } \\
\text { season }\end{array}$ \\
\hline Vegetation (developments stage) & 565.08 & 750.44 & 40 & 40 & 16 & 16 \\
\hline Flowering (mid-season stage) & 2621.2 & 2710.9 & 45 & 45 & 24 & 22 \\
\hline Yield formation and repining (end stage) & 1672.7 & 1872.9 & 30 & 30 & 13 & 14 \\
\hline Total & 4858.98 & 5334.24 & 115 & 115 & 53 & 52 \\
\hline
\end{tabular}

\section{B: Relative water content of leaves (RWC)}

The resulted data were analyzed statistically as a complete block design using three replicates (Snedecor and Cochran, 1980). Differences among treatments were tested with LSD at a 5\% level of significance.

\section{RESULTS AND DISCUSSION}

The applied water, relative water content of leaves, canopy temperature, Net $\mathrm{CO}_{2}$ assimilation rate, yield components, chemical fruit quality parameters, irrigation water use efficiency, tomato water response factor, unmarketable yield, and marketable yield values are presented and discussed in following section.

\section{A: Applied Water}

Data of $\mathrm{ET}_{0}$ indicated that the maximum value of $\mathrm{ET}_{0}$ during the growing season of tomato plants was 7.0 $\mathrm{mm} \mathrm{d}^{-1}$ for June. This relatively high value was due to both high temperature and low relative humidity. The highest value of daily ETc $\left(8.25 \mathrm{~mm} \mathrm{~d}^{-1}\right)$ was recorded for mid-season growth stages (flowering, fruit set, and fruit formation) with $\mathrm{Kc}$ value of 1.21. This (midseason) growth stages were in May and Jun. Data presented in Table (1) showed that the highest values of water consumptive use were (flowering stage) 2621.2 $\mathrm{m}^{3} \mathrm{ha}^{-1}$ through 45 days within 24 irrigations for the first season and $2710.9 \mathrm{~m}^{3} \mathrm{ha}^{-1}$ through 45 days within 22 irrigations for the second season. The lowest values of water consumptive use were (development stage) $565.08 \mathrm{~m}^{3} \mathrm{ha}^{-1}$ and $750.44 \mathrm{~m}^{3} \mathrm{ha}^{-1}$ through 40 days within 16 irrigations for the first and second season, respectively. The latter stage consumed low water because it occurred during March and April where the $\mathrm{ET}_{0}$ is $5.4 \mathrm{~mm} \mathrm{~d}^{-1}$. Total amounts of applied water were $4950.05,3720.83$, and $2647.33 \mathrm{~m}^{3} \mathrm{ha}^{-1}$, for water regimes of $100 \% \mathrm{ETc}, 75 \% \mathrm{ETc}$ and $50 \% \mathrm{ETc}$, respectively, for the first season. The corresponding amounts were 5334.28, 3964.69, and $2772.01 \mathrm{~m}^{3} \mathrm{ha}^{-1}$, respectively, for the second season. Obviously, there are slight differences in the consumed water between the two seasons. 
RWC values were shown in Figure (1). The RWC had high values at $100 \%$ ETc water regime compared to $50 \%$ ETc for both growing seasons. The reduction in RWC was relevant to the levels of soil water content. The RWC under the irrigation regimes followed the order: $100 \% \mathrm{ETc}>75 \% \mathrm{ETc}>50 \% \mathrm{ETc}$. The values of RWC values were lower by 4.8 and $11.5 \%$ for the $75 \% \mathrm{ETc}$ and $50 \% \mathrm{ETc}$, respectively as compared to $100 \%$ ETc for the first season. This could be attributed to the high evaporative demand of the atmosphere, and also to relatively low root ability to absorb water from the soil. Generally, Applications of ATs were effective in improving RWC under unfavorable soil moisture i.e., $50 \% \mathrm{ETc}$ as well as $75 \% \mathrm{ETc}$. The enhancement of ATs for the RWC was more pronounced under $75 \%$ ETc than the $50 \% \mathrm{ETc}$ in comparison to the control treatments. The improvement in RWC may be attributed to the decrease in water loss and improved water uptake by plant roots using ATs. Effects of KA on RWC could be attributed to its light reflective nature which had reduced the absorption of radiant energy and consequently transpiration reduction (Glenn et al., 2003). Effects of FA on RWC can be attributed to water uptake by roots as well as water conductance (Anjum et al., 2011). The presented results are in agreement with those reported by Prakash and Ramachandran (2000a);
Moftah and AL-humaid (2005); Cantore et al., (2009) and Anjum et al., (2011).

\section{C: Canopy Temperature $(\mathrm{Ct})$}

$\mathrm{Ct}$ values were presented in Table (2). For the first season, the mean $\mathrm{Ct}$ values were 26.35, 28.19, and $28.26{ }^{\circ} \mathrm{C}$ for 100,75 , and $50 \%$ ETc, respectively, during mid-day period. Afternoon period, the corresponding values were $24.61,24.81$ and $25.67{ }^{\circ} \mathrm{C}$. Similar $\mathrm{Ct}$ trend was reported for the second season. It is obvious that differences in $\mathrm{Ct}$ were great in the mid-day period compared to the afternoon period. These differences are attributed to the great amount of solar radiation received by plant canopy during the mid-day period. At the end of the day, all treatments almost had the same $\mathrm{Ct}$. Application of Kaolin reduced significantly $\mathrm{Ct}$ compared to the control (untreated plants) for both 75 and $50 \%$ ETc, particularly at the mid-day, when incident solar radiation was high. KA spraying reduced tomato $\mathrm{Ct}$ of the $50 \%$ ETc treated plants by about 2.9 and $2.3{ }^{\circ} \mathrm{C}$ for the mid-day, and afternoon respectively, compared to its control treatment. Increased reflection of incident radiation from the white colored kaolinsprayed leaves was probably responsible for the $\mathrm{Ct}$ reduction.

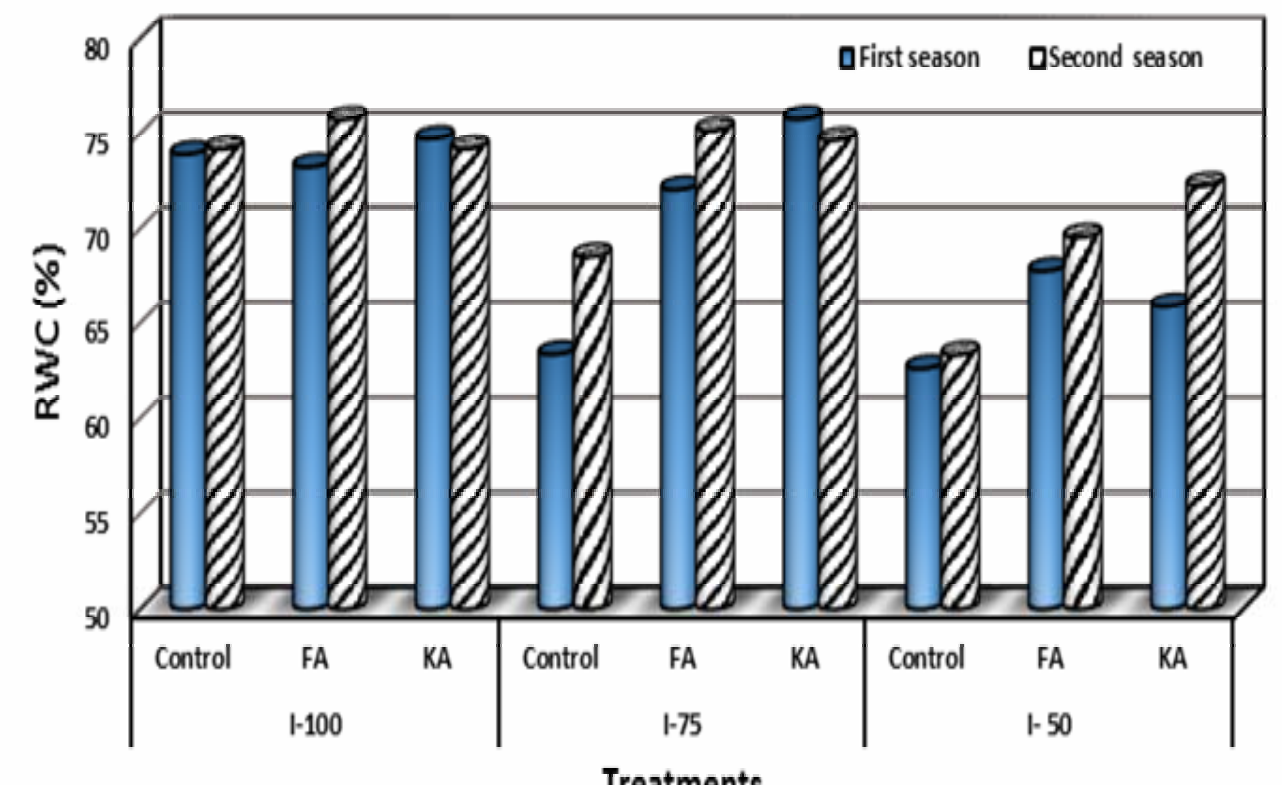

Fig. 1. The relative water content (RWC) of leaves as influenced by water regimes and antitranspirants foliar applications

Table 2. Effect of water regimes and antitranspirants treatments on the canopy temperature 


\begin{tabular}{|c|c|c|c|c|c|}
\hline \multirow{2}{*}{\multicolumn{2}{|c|}{ Experimental Treatments }} & \multicolumn{4}{|c|}{ Canopy temperature ${ }^{\circ} \mathrm{C}$} \\
\hline & & \multicolumn{2}{|c|}{ First season } & \multicolumn{2}{|c|}{ Second season } \\
\hline Irrigation & ATs & $\begin{array}{l}\text { Mid-day } \\
\text { 1-2 pm }\end{array}$ & $\begin{array}{c}\text { late } \\
\text { afternoon } \\
5-6 \mathrm{pm}\end{array}$ & $\begin{array}{l}\text { Mid-day } \\
\text { 1-2 pm }\end{array}$ & $\begin{array}{c}\text { Later } \\
\text { Afternoon } \\
5-6 \mathrm{pm}\end{array}$ \\
\hline \multirow{4}{*}{$100 \%$} & Control & 26.82 & 24.87 & 26.01 & 21.15 \\
\hline & FA & 26.21 & 24.57 & 27.85 & 22.96 \\
\hline & KA & 26.02 & 24.38 & 22.72 & 20.84 \\
\hline & mean & 26.35 & 24.61 & 25.53 & 21.65 \\
\hline \multirow{4}{*}{$75 \%$} & Control & 28.36 & 24.49 & 28.78 & 24.14 \\
\hline & FA & 30.02 & 24.78 & 29.22 & 23.10 \\
\hline & $\mathrm{KA}$ & 26.21 & 25.16 & 25.86 & 21.80 \\
\hline & mean & 28.19 & 24.81 & 27.95 & 23.01 \\
\hline \multirow{5}{*}{$50 \%$} & Control & 30.11 & 26.24 & 31.80 & 25.83 \\
\hline & FA & 27.95 & 25.78 & 31.88 & 23.99 \\
\hline & KA & 26.72 & 24.99 & 28.12 & 22.28 \\
\hline & mean & 28.26 & 25.67 & 30.60 & 24.03 \\
\hline & $\mathrm{O}_{0.05}$ & 0.43 & 0.38 & 1.01 & 0.85 \\
\hline
\end{tabular}

Kaolin effects on $\mathrm{Ct}$ of tomato agree with those obtained for many tree species including apple, pomegranate, pecan, walnut, almond, grapefruit, pear and citrus. For all of them kaolin reduced leaf $\mathrm{Ct}$ by $1-6$ ${ }^{\circ} \mathrm{C}$ (Jifon and Syvertsen, 2003; Wünsche et al., 2004; Lombardini and Glenn, 2005 and Rosati et al., 2006). While ATs of the reflecting type cause a reduction in $\mathrm{Ct}$, the stomata-closing types tend to increase leaf temperature by curtailing (TR) and thus reducing evaporative cooling. In contrarily, the FA effects on $\mathrm{Ct}$ were not numinous. Some FA treatments possessed higher $\mathrm{Ct}$ than its control. These increases might be due to film applications that minimize transpiration cooling; but the increase in temperature is minimal as transpiration only removes part of the energy budget of the leaf and rarely is the leaf completely coated. By the end of the day, all treatments had almost the same $\mathrm{Ct}$ implying that longwave emittance was unaffected by ATs sprays.

\section{D: Net $\mathrm{CO}_{2}$ Assimilation Rate}

Data of net $\mathrm{CO}_{2}$ AR (Figure 2) showed that the values of net photosynthesis rates were higher at $100 \%$ ETc water regime as compared to either 75 or $50 \%$ ETc water regimes. Net $\mathrm{CO}_{2}$ AR means were 14.29, 12.59 and $11.26 \mu \mathrm{mol} \mathrm{CO}_{2} / \mathrm{m}^{2}$.s for 100,75 , and $50 \% \mathrm{ETc}$, respectively, in the first season. The corresponding rates were $13.52,12.61$ and $9.80 \mu \mathrm{mol} \mathrm{CO}_{2} / \mathrm{m}^{2}$.s for the second season. These results are in agreement with those found by Rosati et al., (2006) and Moftah and AL-humaid, (2005).

This reduction in photosynthesis rate under water stress conditions could be ascribed to the high evaporative demand of the atmosphere and relatively low root ability to absorb water from the soil. It is obvious that roots are the first plant organ response to water stress and send chemical signals through the stem to leaves, where stomatal conductance is reduced (Taiz and Zeiger, 2002). The 'non-stomatal' mechanisms include changes in chlorophyll synthesis, functional and structural changes in chloroplasts and disturbances in processes of accumulation, transport and distribution of assimilates (Farooq et al., 2009a, b). Also, drought stress disrupts the photosynthetic pigments, causing irreversible damage to the photosynthetic apparatus, reducing gas exchange, leading to reduction in plant growth and productivity (Anjum et al., 2011). Reduction of photosynthesis rate is correlated to low RWC under water deficit conditions as reported previously. Under all water regimes, the photosynthesis rates under both ATs treatments differed insignificantly. For instance under $75 \%$ ETc, the rate decreased nonsignificantly by $4.36 \%$ and $16.27 \%$ for FA and KA, respectively. This reduction was not significant because of the water deficit is low all over the growing season. The data of the second season are in agreement with those found in the first season. However, these considerations of leaf measurements cannot be scaled up from the leaf to the whole canopy because, in the latter, most leaves are exposed (and adjusted) to less than saturating photosynthesis active radiation (Wünsche et al., 2004). Also, the reduction of the photosynthesis rate was relevant to the reduction in applied water more than the effect of the type of ATs. Similar results were found by Rositi et al. (2006). Some hypotheses have been formulated to explain the variances in the obtained different results. Particle films have been shown to reduce the light available to the leaf by increasing light reflection (Wünsche et al., 2004). This can reduce leaf net photosynthesis of leaves under 
optimal conditions for photosynthesis. However, at high temperature, net photosynthesis of leaves may be more limited by the heat stress than by low light so that the reduction in leaf temperature, induced by the kaolin film, could be more than compensate for the negative effect of reduced light (Glenn et al., 2003). The results of Kaolin coated leaves in the present study are in agreement with those obtained for apple (Grange et al., 2004; and Srinivasa, 2010). Also, Moftah and AlHumaid (2005) observed that the gas exchange of Kaolin sprayed-plants under water stress conditions (plants irrigated with $60 \%$ of water added to control well-irrigated treatments) did not reach the values obtained in control plants.
Figure (3) showed that marketable yield was reduced by $48.32 \%$ and $20.07 \%$ for $50 \% \mathrm{ETc}$ and $75 \% \mathrm{ETc}$ treated plants, respectively with reference to the $100 \%$ ETc in the first season. Low reduction rate was recorded for the second season compared to the first season. The yield reduction could be attributed to the decrease of photosynthesis rate as presented earlier. On contrast, unmarketable yield (Figure 3) increased as water stress increased. Unmarketable yield was increased by $53.17 \%$ and $9.52 \%$ for $50 \% \mathrm{ETc}$ and $75 \%$ ETc treatments respectively for the first season. The corresponding reductions were $70.00 \%$ and $44.72 \%$ for the second season.

\section{E: Yield Components}

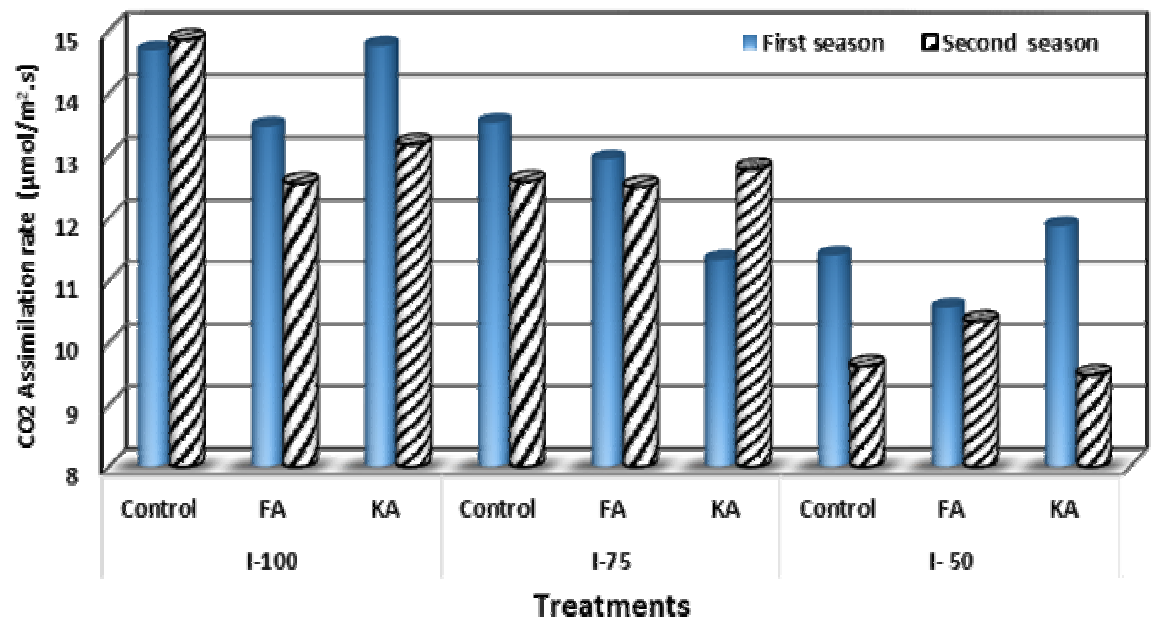

Fig. 2. Effect of water regimes and antitranspirants foliar application on $\mathrm{CO}_{2}$ assimilation rate $\left(\mu \mathrm{mol} / \mathrm{m}^{2} . \mathrm{s}\right)$

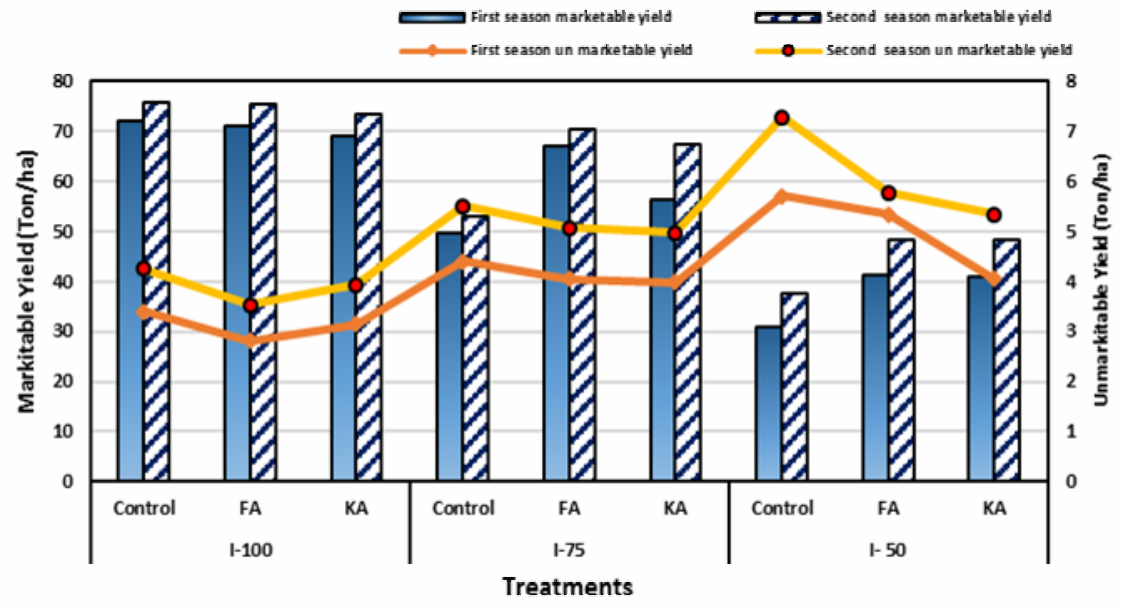

Fig. 3. Effect of water regimes and antitranspirants foliar application on marketable and unmarketable yield (Kg ha $\left.{ }^{-1}\right)$ 
This is possibly related to the increase in sunburned fruit, damaged by insects, and those affected by the blossom end rot. These obtained results are in agreement with those found by Rosati et al. (2006), Cantore et at. (2009) and Savic et al. (2011).

The ATs foliar spray enhanced the marketable yield under both $50 \% \mathrm{ETc}$ and $75 \% \mathrm{ETc}$ treatments compared to their control treatments. For 50\% ETc treatment, the values of marketable yield increased by $24.97 \%$ and $24.51 \%$; and $28.43 \%$ and $27.88 \%$ for FA and KA, in the first and second season, respectively, compared to their control treatments. For $75 \%$ ETc treatments, marketable yield increased insignificantly as compared to the control for KA and increased significantly with the metabolic inhibitor FA for the first season. Both ATs significantly increased marketable yield in the second season. Marketable yield increased by about $25.8 \%$ and $11.73 \%$; and $23.68 \%$ and $21.20 \%$ for FA and KA, in the first and second season, respectively comparison to their control treatments. Such yield improvements could be attributed to the reduction of TR as a result of the ATs foliar application. This reduction of TR led to soil water conservation, thus the yield increased compared to control. It is worth noting that under deficit irrigation; reducing water loss would conserve soil moisture for a longer time and could result in yield improvement in arid and semi-arid regions for tomato. Under well irrigation conditions, values of marketable yield reduced slightly, the reduction was not significant for the two ATs. These results are in accordance with those found by Glenn et al. (2002), Jifon and Syvertsen (2003) and

Table 3. Effect of water regimes and antitranspirants treatments on chemical fruit quality

\begin{tabular}{|c|c|c|c|c|c|c|c|}
\hline \multirow{2}{*}{\multicolumn{2}{|c|}{ Experimental Treatments }} & \multicolumn{6}{|c|}{ Chemical Fruit Quality } \\
\hline & & \multicolumn{3}{|c|}{ First season } & \multicolumn{3}{|c|}{ Second season } \\
\hline Irrigation & ATs & $\begin{array}{c}\text { Vit. C } \\
\mathrm{mg} / 100 \mathrm{ml}\end{array}$ & $\begin{array}{c}\text { Titrable Acidity } \\
\text { mg/100ml }\end{array}$ & $\begin{array}{c}\text { TSS } \\
\text { (Brix) }\end{array}$ & $\begin{array}{c}\text { Vit. C } \\
\mathrm{mg} / 100 \mathrm{ml}\end{array}$ & $\begin{array}{c}\text { Titrable } \\
\text { Acidity } \\
\text { mg/100ml }\end{array}$ & $\begin{array}{l}\text { TSS } \\
\text { (Brix) }\end{array}$ \\
\hline \multirow{4}{*}{$100 \%$} & Control & 25.6 & 0.17 & 7.33 & 23.1 & 0.2 & 6.03 \\
\hline & FA & 25.8 & 0.19 & 7.08 & 21.6 & 0.2 & 6.13 \\
\hline & KA & 28.2 & 0.18 & 7.23 & 21.2 & 0.19 & 6.20 \\
\hline & mean & 26.53 & 0.18 & 7.21 & 21.97 & 0.19 & 6.12 \\
\hline \multirow{4}{*}{$75 \%$} & Control & 27.4 & 0.16 & 6.67 & 22.0 & 0.21 & 5.90 \\
\hline & FA & 24.9 & 0.17 & 7.28 & 22.2 & 0.18 & 5.60 \\
\hline & $\mathrm{KA}$ & 28.6 & 0.18 & 7.54 & 20.2 & 0.20 & 5.73 \\
\hline & mean & 26.97 & 0.17 & 7.16 & 21.47 & 0.19 & 5.74 \\
\hline \multirow{4}{*}{$50 \%$} & Control & 26.1 & 0.18 & 6.87 & 21.0 & 0.20 & 5.94 \\
\hline & FA & 28.4 & 0.16 & 6.72 & 23.1 & 0.20 & 6.50 \\
\hline & KA & 26.3 & 0.18 & 8.15 & 21.0 & 0.21 & 6.03 \\
\hline & mean & 26.93 & 0.17 & 7.25 & 21.70 & 0.20 & 6.16 \\
\hline \multicolumn{2}{|c|}{$\mathrm{LSD}_{0.05}$} & 4.66 & 0.03 & 0.87 & 3.78 & 0.02 & 0.61 \\
\hline
\end{tabular}

Contore et al. (2009). The potential of both ATs to increase marketable yield was more pronounced under $50 \%$ ETc than $75 \%$ ETc. For example, the marketable yield of FA-treated plants increased by 4.97, 25.8, and $1.25 \%$ for $50 \% \mathrm{ETc}, \quad 75 \% \mathrm{ETc}$ and $100 \% \mathrm{ETc}$, respectively comparison to their controls. Similarly, the marketable yield of KA-treated plants increased by $24.51,11.73$ and $-4.18 \%$ for $50 \% \mathrm{ETc}, 75 \% \mathrm{ETc}$ and $100 \% \mathrm{ETc}$, respectively. These results agree with those found by Saavedra et al. (2006) and Pace et al. (2007). Taking the $100 \%$ ETc treatment as a reference, there were no significant difference between marketable yield for plants sprayed with FA at $75 \% \mathrm{ETc}$ and the control at $100 \%$ ETc. This indicates that FA application is effective in reducing TR at $75 \%$ ETc more than Kaolin. Thus, FA application would reduce the applied water by $25 \%$ per irrigation with a maximum reduction in yield was nearly $6.7 \%$. This gives an impression that the use of FA would be an effective tool to alleviate heat stress and to reduce water stress for tomato production grown under arid and semi-arid conditions.

\section{F: Chemical Fruit Quality Parameters}

The fruit quality parameters include TSS, titratable acidity and Vit. C. Their values were shown in Table (3). They did not differ significantly among the studied treatments. Similar results were reported by Birhanu et al. (2010) and Savic et al. (2011). For both titratable acidity and Vitamin (C) values, there were no significant differences between plants treated with any ATs. Kaolin application under 50\%ETc increased fruit TSS by $18.63 \%$ compared to the control treatment. 
The results of Kaolin agreed with those reported by Prakash and amachandran (2000a) and Saavedra et al. (2006).

\section{G: Irrigation Water Use Efficiency (IWUE)}

Data of IWUE were illustrated in Figure (4). Under $75 \% \mathrm{ETc}$ treatment, IWUE increased by $1.25 \mathrm{Kg} \mathrm{m}^{-3}$ and $1.93 \mathrm{Kg} \mathrm{m}^{-3}$ amounting to $8.76 \%$ and $13.72 \%$ compared to its values under $100 \% \mathrm{ETc}$ irrigation treatment for the first and second seasons, respectively. Under $50 \% \mathrm{ETc}$ treatments, the value of IWUE was changed slightly and was corresponding to $0.10 \%$ lower than those under $100 \%$ ETc treatments for the first season. The corresponding value was higher by $4.75 \%$ for the second season. This could be attributed to the high drop in the marketable yield, as tomato is a sensitive crop to water stress. Such increase in IWUE is relevant to deficit irrigation studies for tomato cultivars (Costa et al., 2007 and Patanèa et al., 2011). The IWUE increased by $33.24 \%$ and $32.47 \%$ for FA and KA, respectively, in comparison to their control treatments for the first season $(\% 50 \mathrm{ETc})$. The corresponding values were $31.76 \%$ and $31.52 \%$ for $\mathrm{FA}$ and $\mathrm{KA}$, respectively for the second season. Such improvements could be attributed to the reduction of TR since reducing rate of water loss would conserve soil moisture for a longer time and could result in yield improvement. Regarding 75\%ETc, IWUE increased as compared to the control by $34.82 \%$ and $13.30 \%$, and $30.99 \%$ and $26.88 \%$ for FA and KA, in the first and second season, respectively. Under optimal irrigation treatments, the values of IWUE decreased slightly. However, the reduction was not significant for the two ATs treatments. These results contradict to those found by Contore et al. (2009) but agree with results reported by Glenn et al. (2001) and Jifon and Syvertsen (2003) for apple and grapefruit. The superiority of Fulvic acid (FA) over kaolin (KA) may be due to the reduction of
TR which is caused by stomata regulators which prevented stomata from opening fully thus decreasing the loss of water vapor from the leaf.

\section{H: Tomato Water Response Factor (Ky)}

Values of Ky were shown in Figure (5). They decreased under irrigation of $50 \%$ ETc. The reduction was much greater under irrigation regime of $75 \% \mathrm{ETc}$ than under $50 \%$ ETc. However, the reduction in water response factor for each water unit under $75 \%$ ETc treatments is lower than that under the $50 \%$ ETc treatment.

It is clear from Figure (5) that the values of $\mathrm{Ky}$ factor were $1.06,0.89$, and 1.02 for $50 \% \mathrm{ETc}, 75 \% \mathrm{ETc}$, and $100 \%$ ETc treatments for the first season, and were $0.99,0.81$ and 1.01 , for the second season, respectively. This indicates that plants irrigated with $100 \%$ ETc were more sensitive to water stress, whereas the presence of Ky with the lowest value under $75 \%$ ETc showed that under this treatment, tomato is more capable to tolerate water stress in comparison with the other irrigation treatments. Under severe water stress treatments $(50 \%$ ETc), the two ATs foliar spray treatments reduced Ky values significantly by $24.6 \%$ and $24.6 \% ; 25.9 \%$ and $25.9 \%$ for FA and KA, in the first and second seasons, respectively as compared to the control treatment.

These improvements could be attributed to the reduction of TR and thus to soil water conservation, which make tomato plants less sensitive to water stress. Under $75 \%$ ETc water regime, the data of the first and second seasons revealed that Ky was reduced as compared with the control treatment by $78.2 \%$ and $29.8 \%$ and by $72.6 \%$ and $63.2 \%$ for FA and $\mathrm{KA}$, respectively. Under $75 \%$ ETc water regime, there was no significant variation between the two investigated ATs treatments. This may be due to the reduction in the $\mathrm{TR}$ and the photosynthesis rate.

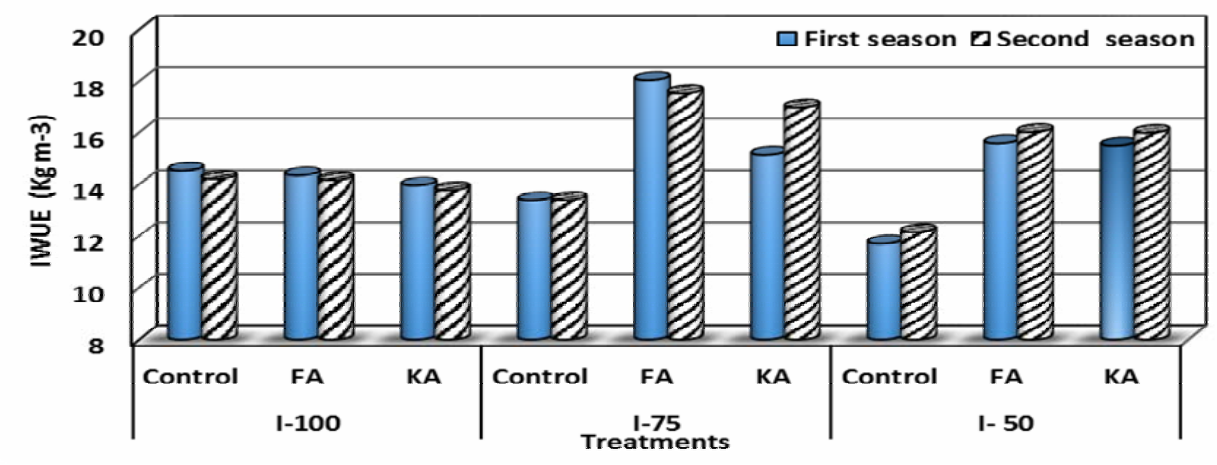

Fig. 4. Irrigation water use efficiency (IWUE) $\left(\mathrm{Kg} \mathrm{m}^{-3}\right)$ as influenced by water regimes and ATs foliar application 


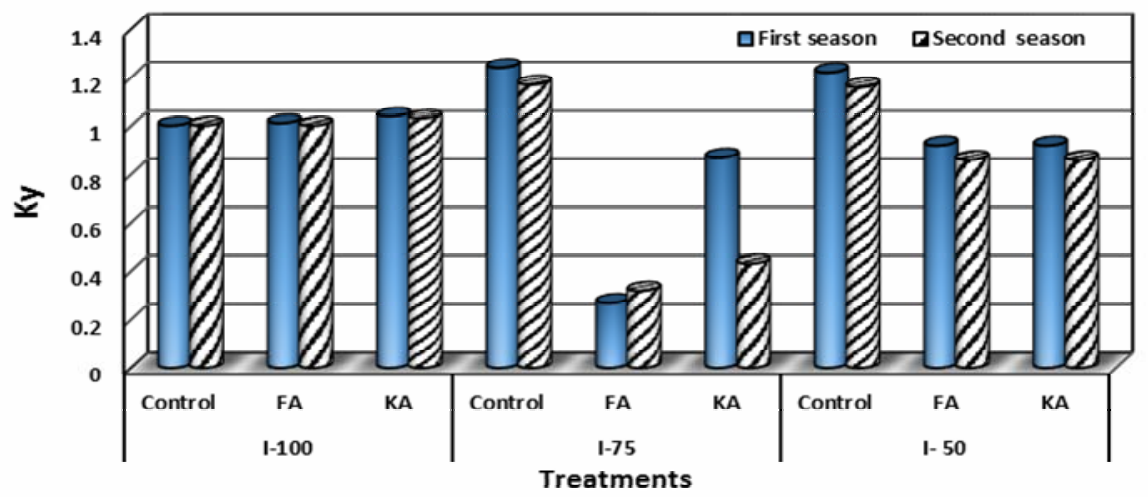

\section{Fig. 5. Crop water response factor (Ky) as influenced by water regimes and ATs foliar application}

\section{CONCLUSION}

While low water regime $(50 \% \mathrm{ETc})$ significantly reduces relative water content (RWC) of tomato leaves, photosynthesis rate and marketable yield, the application of both ATs' types (KA and FA) under deficit water irrigation enhanced effectively the physiological activities and yield production of tomato plants, particularly under moderate water stress $(75 \% \mathrm{ETc})$. It is clear that tomato plant did not compensate the negative effects caused by the $50 \% \mathrm{ETc}$ irrigation regime. However, Fulvic acid was more effective than Kaolin. Under $75 \% \mathrm{ETc}$, foliar spray with $1.5 \mathrm{ml} \mathrm{FA} \mathrm{L}^{-1}$ at fruit set stage (21-day intervals) produced the minimum reduction of net $\mathrm{CO}_{2} \mathrm{AR}$ and yield. As a result, IWUE increased by $34.82 \%$ with respect to well irrigated $(100 \% \mathrm{ETc})$ - ATs untreated plants. Furthermore, FA application led to conserving soil water and thereby reducing the quantity of the applied water by $25 \%$ per irrigation without serious yield reduction, at the same time, fruit quality parameters were sustained.

\section{REFERENCES}

Allen, R. G., S.L, Pereira, D. Raes, and M. Smith. 1998. Crop Evapotranspiration Guideline For Computing Crop Water Requirements. Irrigation and Drainage Paper No. 56. FAO. Rome.

Anandacoomaraswamy, W.A., J.M. De Costa, H.W. Shyamalie, and G.S. Campbell. 2000. Factors controlling transpiration of mature field-grown tea and its relationship with yield. J.Agric. Forest Meteorol. 103: 375-386.

Anjum, S. A., L. Wang, M. Farooq, L. Xue, and S. Ali. 2011. Fulvic acid application improves the maize performance under well-watered and drought conditions. J. Agron. Crop Sci. N 0931-2250.

Birhanu, K., and K. Tilahun .2010. Fruit yield and quality of drip-irrigated tomato under deficit irrigation. Ajfand on line. 10 (2): 2139-2151.
Cantore, V., B. Pacea, and R. Albriziob .2009. Kaolin based particle film technology affects tomato physiology yield and quality. J.Environ. and Experim. Botony. 66: 279-288.

Costa, M., M.F. Ortuno, and M.M. Chaves. 2007. Deficit irrigation as a strategy to save water. physiology and potential application to horticulture. J. Integ. Plant Biol. 49 (10): 1421-1434.

De Pascale, S., C. Ruggiero, G. Barbieri, and A. Maggio .2003. Physiological response of pepper to salinity and drought. J. Amer. Soc. Hort. Sci. 128: 48-54.

Farooq, M., A. Wahid, D.J. Lee, and K.H.M. Siddique .2009b. Advances in drought resistance of rice. Crit. Rev. Plant Sci. 28: 199-217.

Farooq, M., A. Wahid, N. Kobayashi, D. Fujita, and S. M. A. Basra. 2009a. Plant drought stress effects, mechanisms and management. J. Agron. Sustain. Dev. 29: 185-212.

Glenn, D.M. Glenn, G.J. Puterka, S.R. Drake, T.R. Unruh, A.L. Knight, P Baherie, E. Prado and T. A. Baugher. 2001. Particle film application influences apple leaf physiology, fruit yield, and fruit quality. J. Am. Soc. Hort. Sci. 126: 175-181.

Glenn, D. M., E. Prado, A. Erez, J.R. Mc Ferson, and. G. J. Puterka. 2002. A reflective, processed-kaolin particle film affects fruit temperature, radiation reflection, and solar injury in apple. J. Amer. Soc. Hort. Sci. 127: 188-193.

Glenn, D. M., A. Erez, G. J. Puterka and. P Gundrum. 2003. Particle films affect carbon assimilation and yield in empire' apple. J. Amer. Soc. Hort. Sci. 128: 356-362.

Glenn, D.M., S. Drake. J.A. Abbott., G.J. Puterka, and Gundrum P. 2005. Season and cultivar influence the fruit quality response of apple cultivars to particle film treatments. J. Hort. Tech. 15: 249-253.

Grange, M-le., S.J. E Wand, and K. L. Theron. 2004. Effect of kaolin applications on apple fruit quality and gas exchange of apple leaves. Acta Horti. 636: 545-550. 
Gupta, N. K., G. Sunita, and K. Arvind .2001. Effect of water stress on physiological attributes and their relationship with growth and yield of wheat cultivars at different stages. J. Agron. Crop Sci.186: 55-62.

Jifon, J. L., and J. P. Syvertsen. 2003. Kaolin particle film applications can increase photosynthesis and water use efficiency of 'ruby red' grapefruits leaves. J. Am. Soc. Hortic. Sci.128: 107-112.

Li, M. S., S. Li, and B. L. C. Zhang.2005. Physiological effect of new FA antitranspirant on winter wheat at ear filling stage. J. Agric. Sci. China. 4: 820-825.

Lombardini, L. and D. M. Glenn .2005. Application of kaolinbased particle film on pecan trees. consequences on leaf gas exchange. stem water potential, nut quality, and insect populations. Hort. Sci., 39: 857-858.

Moftah, A. E., and A. R. I. Al-Humaid .2005. Effects of antitranspirants on water relations and photosynthetic rate of cultivated tropical plant (Polianthes tuberosa L.), Pol. J. Ecol, 53:165-175.

Nardi, S. D. Pizzeghello, A. Muscolo, and A. Vianello. 2002. Physiological effects of humic substances on higher plants. J. Soil Biol. Biochem. 34: 1527-1536.

Pace, F. B, V. Cantore, L. Leo, S. Vanadia, E. D Palma and N. Phillips .2007. Effect of particle film technology on temperature, yield and quality of processing tomato. Acta Horti. 758: 287-293.

Patanèa, C., T. Simona, S. Orazio. 2011. Effects of deficit irrigation on biomass, yield, water productivity and fruit quality of processing tomato under semi-arid mediterranean climate conditions. J.Scientia Hort. 129: 590-596.

Prakash, M., K. Ramachandran. 2000a. Effects of chemical ameliorants in brinjal (solanum melongena L.) Under moisture stress conditions. J. Agron. Crop Sci. 185: $237-$ 239.
Prakash, M., K. Ramachandran. 2000b. Effects of moisture stress and anti-transpirants on leaf chlorophyll. J. Agron. Crop Sci. 184: 153-156.

Rosati, A., S.G. Metcalf, R.P. Buchner, Fulton A. E., and Lampinen B. D. 2006. Physiological effects of kaolin applications in well-irrigated and water-stressed walnut and almond trees. Ann. Bot. 98 267-275.

Russo, V.M., and J.C. Díaz-Pérez. 2005. Kaolin-based particle film has no effect on physiological measurements, disease incidence or yield in peppers. J. Hort. Sci. 40: 98-101.

Saavedra, R. G. D., Escaff M.G., and J. V. Hernandéz. 2006. Kaolin effects in processing tomato production in chile. Acta Hortic. 724: 191-198.

Savic, S., R. Stikic, Z. Jovanovic, B. Vucelic-Radovic, M. Paukovic, and S. Djordjevic. 2011. Deficit irrigation strategies for production of tomato in greenhouse conditions. proceedings of the $46^{\text {th }}$ croatian and 6th international symposium on agriculture, Opatia, Croatia. 567-570.

Singh Y., S.S. Rao and O.L. Regar. 2010. Deficit irrigation and nitrogen effects on seed cotton yield, water productivity and yield response factor in shallow soils of semi-arid environment. Agric. Wat. Manag. 97: 965-970.

Snedecor, G. W., W. G. Cochran. 1980. Statistical Methods, $18^{\text {th }}$ ed. The Iowa State College Press. Ames, Iowa, USA.

Srinivasa, N.K. 2010. The effects of antitranspirants on stomatal opening, and the proline and relative water contents in the tomato. J. Hort. Sci. Biotech. 61: 369-372.

Taiz, L., and E. Zeiger.2002. Stress Physiology. [In: Plant Physiology, 3rd ed] Ed. Taiz L. and Zeiger E.- Sinauer Associates, Inc., publishers, Sunderland, Massachusetts, USA,591-620.

Wünsche, J.N., L. Lombardini, and D. H. Greer. 2004. 'Surround' particle film applications-effects on whole canopy physiology of apple. Acta Hortic. 636: 565-571. 


\section{المالضص العري}

\section{تأثير الكالولن وحمض الفالفيك كمضادل النتح عل نبلتالت اللمهلم النامية تحت مستوبلت ميلمختلفة}

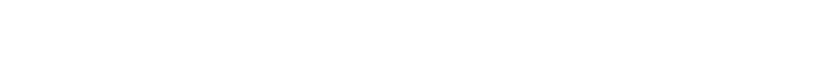

المائى القلهى (ETc

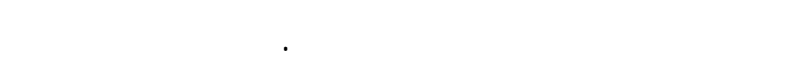

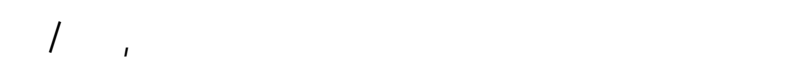

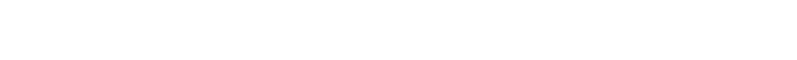
(IWUE)

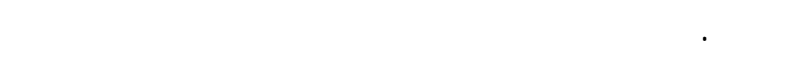
القص للمحصول Ky ألثر من الكاولين خلايل موضسمي

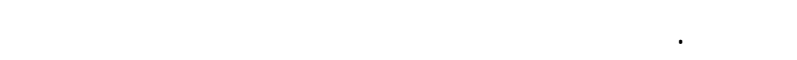

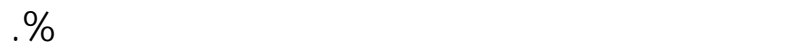

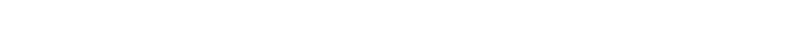

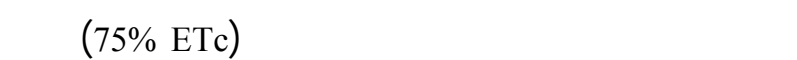

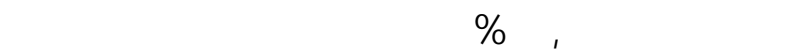

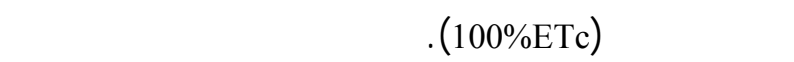

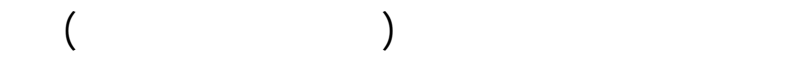
معلملت الرش بمضادات النتح.
لجريت هذه الدرلسة لقيم تأثير الكاولين وحمض المارض الفالفيك كمضادات للنتح على المحتوى الرطوبى النسب

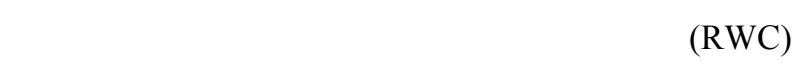

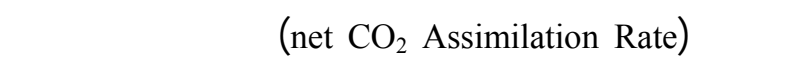

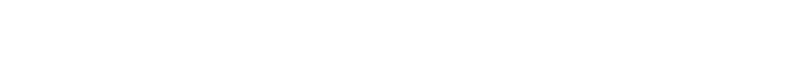

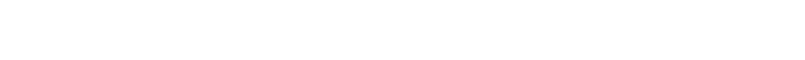

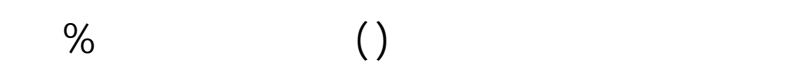

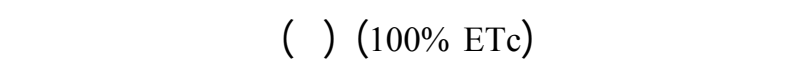

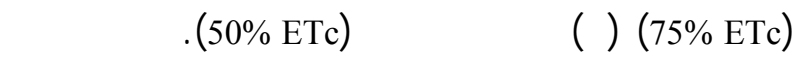

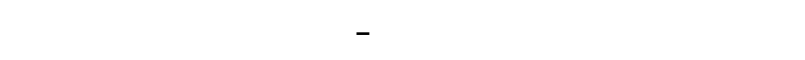

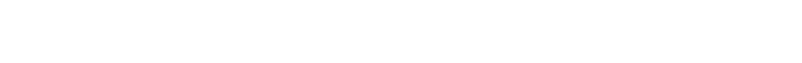
البستان بمحلظة البحيرة. أوضحت النتائج لن كلا النوعن من مضادات النتح النحائح

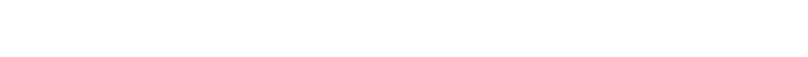

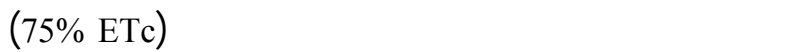
ولكنها لم تعوض التأثيرات للسلبية الناتجة عن القص المصائ 